\title{
The effect of artificial drying on the energy value of grass
}

\author{
By A. EKERN*, K. L. BLAX'TER ANd D. SAWERS \\ Hannah Dairy Research Institute, Ayr \\ (Received 23 March 1965-Accepted 4 May 1965)
}

From the results of a large series of calorimetric studies with artificially dried grasses (Armstrong, r 964), it was found that the value of a dried grass as an energy source for sheep could be predicted from considerations of its species and its chemical composition (Armstrong, Blaxter \& Waite, 1964). The question arises whether the nutritive value of fresh grass can be inferred from that of dried grass, and whether the conclusions drawn for dried grass apply equally to fresh.

There is evidence that the apparent digestibility of grass is slightly impaired by artificial drying (Dijkstra, 1956). Work in New Zealand (Johns, 1955; Christian \& Williams, 1957), in Switzerland (Prabucki, 1963; Prabucki \& Crasemann, 196r) and in this country (El-Shazly, I952) has drawn attention to small differences in composition as between rumen liquor in sheep given fresh or frozen grass (frozen grass being regarded by Swiss workers as synonymous with fresh grass) and the rumen liquor of sheep given artificially dried grass or hay. The only study of the effect of artificial drying of herbage on its value as an energy source that we have traced is that by Heinzl (1944). Heinzl found that artificial drying of herbage resulted in a reduced energy retention estimated from the retentions of carbon and nitrogen when sheep were given supplements of fresh or dried grass.

The experiments now described were made to find whether the energy of the same sample of grass was utilized differently when fresh and when dried.

\section{EXPERIMENTAL}

General. Grass during the growing season can change in composition very rapidly, and the basic experimental design was arranged so that the same herbage was given when fresh and when dried. Each of the three experiments in which comparisons of fresh and dried herbage were made conformed to the same general plan. Deviations from this plan are described under each experiment and the general arrangements for one experiment with one sheep were as follows.

A large bulk of grass was cut at $9.00 \mathrm{am}$. This was well mixed and four meals of identical weight were weighed out. At the same time two samples of equal weight were set aside for dry-matter determination and analysis. At 10.00 am the first weighed meal was given to the sheep in the respiration chamber, and the second weighed meal and one analytical sample were placed in a large drying oven. At I0.00 pm the sheep was given the third weighed meal, and the fourth weighed meal

* Present address: Royal Agricultural College, Vollebekk, Norway. 
and the second analytical sample were placed in the oven. The second and fourth weighed meals were removed and quantitatively transferred to paper bags labelled with the date and time after i $\mathrm{h}$ of drying. The two analytical samples were similarly removed, bulked and stored. The process continued for up to 33 days in some experiments, involving accumulation of a dated series of dried meals. These were then given to the same sheep in the sequence in which they were collected. The basic experimental design thus consisted of giving the same sheep the same dry weight of the same herbage when fresh and when artificially dried, and in this way any difficulties that might otherwise have arisen from changes in the composition of the pasture with time would be overcome.

Sheep and their training. The experimental design has the serious defect that observations with dried grass must follow those made with fresh grass and statistically the effect of drying is confounded with time. If the sheep becomes progressively more accustomed to conditions as the experiments proceed, a systematic error will result. The only way of avoiding this bias is to use sheep fully accustomed to conditions. Accordingly, four highly trained Down cross Border Leicester-Cheviot wether sheep were used. These sheep had all spent at least 2 years in calorimetric trials before the experiments began. Sheep 106 and 107 were used in all the experiments and, in addition, during the period between Expts I and 2, they were used as subjects in a further calorimetric experiment. Sheep I04 and 105 had been used in a calorimetric trial before Expt 2 began. All four sheep were kept in a respiration chamber during the 2 weeks before a particular experiment began. The sheep were probably as well accustomed to experimental procedures as it was possible for them to be. Their behaviour was, in fact, that of domestic pets.

Expt $\mathrm{I}$. This experiment was made in August-October 1962 with sheep 106 and 107. The amount of grass dry matter given varied from day to day, the amount of fresh grass weighed being increased by $20 \%$ when the herbage was wet with rain. An average of $\mathbf{I}^{\cdot} \mathrm{I} \mathrm{kg}$ was given daily. Fresh grass was given for 33 days and continuous calorimetric observations were made for the last 20 days. A similar routine was adopted with the dried grass. The evening meal of fresh grass in this experiment was placed in the manger of the respiration chamber at $10.00 \mathrm{am}$. The manger was opened at $10.00 \mathrm{pm}$, the chamber remaining closed for the whole $24 \mathrm{~h}$. Any $\mathrm{CO}_{2}$ produced or $\mathrm{O}_{2}$ consumed during respiration of the grass between 10.00 am and I $0.00 \mathrm{pm}$ would thus be interpreted as resulting from the respiration of the animal. Any $\mathrm{CO}_{2}$ produced and $\mathrm{O}_{2}$ consumed by the respiration of the meal destined to be dried at $10.00 \mathrm{pm}$ were lost. A systematic error was therefore involved in this experiment. Measurement of the amounts of $\mathrm{CO}_{2}$ produced from a meal of fresh grass, stored in the manger of the respiration chamber during a $\mathrm{I} 2 \mathrm{~h}$ period, showed that on average $4 \mathrm{~g}$ of $\mathrm{CO}_{2}$ were formed. Since the mean amount formed by the sheep was $\mathrm{r} .069 \mathrm{~kg}$, the error caused in this way was only $0.4 \%$.

Expt 2. This experiment began in May 1963 with all four sheep and consisted of giving fresh grass for 28 days to each, and measuring their metabolism during the last 12 days of each period. Two sheep were used concurrently. Thus the metabolism of sheep 106 and 107 was measured when they were eating grass grown between 
I I May and 7 June, and that of sheep I04 and 105 when they were eating grass grown between 25 May and 2I June. Two changes in design were made. First, the drymatter intake was standardized at $\mathbf{I} \cdot 2 \mathrm{~kg} / \mathrm{day}$ by rapidly drying a sample of the herbage before the meals were weighed. Secondly, the evening meal of fresh grass was stored from 10.00 am to $10.00 \mathrm{pm}$ at the same temperature as its duplicate destined to be dried, and the chamber was opened to insert the meal. This avoided the small systematic error introduced in Expt 1. The chambers were not opened when the evening meals of dried grass were given.

Expt 3. This experiment was made with all four sheep in September-November 1963. Each sheep was given two different amounts of grass dry matter in consecutive periods of 14 days and metabolism was measured from the 9 th to the $14^{\text {th }}$ day inclusive of each period.

The metabolism of two sheep was measured concurrently, one receiving $700 \mathrm{~g}$ dry matter and the other $1 \cdot 4 \mathrm{~kg}$. In this experiment further modification of the design was made. Although two feeds of dried grass could be accommodated in the respiration chamber feed bin, the bin could hold only one feed of fresh grass. When, therefore, fresh grass was being given the chamber was opened a second time in the day to give the evening meal. To eliminate any possibility that this evening opening of the chamber to introduce the fresh grass caused an increase in the metabolism of the sheep by disturbing it, which did not occur when dried grass was being used, the chamber was opened in the evening for the introduction of dried grass as well as for the introduction of fresh grass.

In this experiment $\mathrm{O}_{2}$ consumption was also determined from the time of feeding

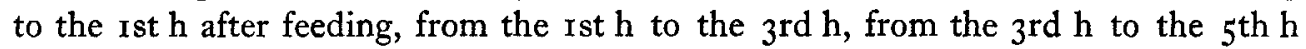
and from the $5^{\text {th }}$ to the $I I$ th $h$ after feeding.

Fasting metabolism. The fasting metabolism of sheep 106 and 107 was determined at the end of Expt I, and that of all four sheep between Expts 2 and 3.

Subsidiary experiment. The major difference between fresh and dried grass is in water content, and in the first experiment it was noted that the total water intake (including drinking water) of the sheep given dried grass was considerably less than that of the sheep given fresh grass. To find the effect of the sudden ingestion of cold water on heat production, a sheep with a rumen fistula was given a constant ration of dried grass and kept in the respiration chamber at $8-10^{\circ}$. When the sheep was fed, i.e. twice daily, either $1 \cdot 51$. or 31 . of water at $5^{\circ}$ were slowly introduced into the rumen. Heat production was measured and compared with that determined when no water was infused.

Drying of the grass. The grass was dried in large trays in a ventilated Unitherm oven (Blackburn Engineering Co. Ltd) at a nominal temperature of $102^{\circ}$. On introduction of the large mass of fresh herbage (on occasions containing $18-19 \mathrm{~kg}$ water) the temperature fell by $15-25^{\circ}$, and only rose to the nominal temperature after the lapse of $\mathrm{I} \frac{1}{2}-2 \mathrm{~h}$. Respiration losses might have occurred early in this interval. This possibility was examined by determining the ash content of the dry matter of fresh grass and of grass dried in the Unitherm oven. The reference dry matter in this instance was that determined in a small sample in a precision analytical laboratory oven 
(Baird \& Tatlock Ltd). It was found that the mean ash content of the dry matter of forty samples of fresh grass was $10.87 \%$ and of the grass dried in the Unitherm oven $10.90 \%$. These figures suggest a loss of $0.3 \%$ of the organic matter by respiration during drying. It is not an absolute measure since some respiration may have occurred during laboratory drying. Mechanical loss during the drying process through convection of dust and shaking of the trays on removal from the oven was checked by weighing the contents of trays of dried grass which were kept in the oven and removed at $24 \mathrm{~h}$ intervals over a period of 5 days. No loss in weight occurred. These tests show that no mechanical loss occurred in drying and that no significant respiratory loss took place.

Calorimetric methods. Two respiration chambers (Wainman \& Blaxter, I958) were used. Faeces were collected daily and analysed either daily (Expt I) or pooled over 4 days (Expt 2) or 5 days (Expt 3), and the bulk was analysed for N, C and energy value. Urine was collected daily, its $\mathrm{N}$ content, $\mathrm{C}$ content and its heat of combustion determined either daily (Expt I) or in $4^{-}$or 5 -day bulked samples (Expts 2 and 3 respectively). The amounts of $\mathrm{O}_{2}$ consumed, and of $\mathrm{CO}_{2}$ and $\mathrm{CH}_{4}$ produced, were determined daily.

Retention of energy was calculated, first from the energy intake and the losses of energy in faeces, in urine, as methane and as heat, the latter being calculated from the gaseous exchange, and secondly from the retentions of $\mathrm{C}$ and $\mathrm{N}$ in the body using the factors of Blaxter \& Rook (1953).

\section{RESULTS}

Composition of the grass. Table I shows the chemical composition and botanical composition of the grass given in each experiment. The results of the chemical analyses are averaged over the whole period of each experiment but those of the botanical analyses are based on examination of one sample each week. The table shows that the herbage in Expts I and 2 consisted largely of ryegrass but that in Expt 3 it was a mixture containing very little ryegrass.

During the course of Expt 2, the herbage was growing rapidly. At the beginning it was $15 \mathrm{~cm}$ high, but at the end of the 42 days all the species of grass were in flower. The protein content of the grass dry matter in fact fell from 16.8 to $9.7 \%$ in 25 days. Changes of such a magnitude did not occur in Expts I and 3 , but during these two experiments some decomposition of the base of the herbage and bleaching of the leaves accurred as the experiments progressed. The decomposition of the base was accentuated by very rainy conditions at the time.

Individual experiments. The results of eight comparisons of the metabolism of sheep given fresh herbage and dried herbage are summarized in Table 2. Each comparison consists of mean values for two sheep, and the results are averaged over the whole of the calorimetric period in Expts 2 and 3 and over two subperiods of ro days in Expt $\mathbf{r}$.

Fig. I shows the mean results obtained in Expt I day by day. In this experiment the dry matter offered varied from day to day. The grass when dried was completely consumed. When given fresh, very small refusals occurred, so that the calorie intake 
Table I. Chemical and botanical composition of the herbage used in the experiments

Expt I $\overbrace{\begin{array}{c}\text { Sheep 106 } \\ \text { and 107 }\end{array}}^{\text {Expt } 2} \underbrace{\text { Expt } 3}_{\begin{array}{c}\text { Sheep 104 } \\ \text { and 105 }\end{array}}$

Chemical composition ( $\%$ of dry matter)

$\begin{array}{lrrrr}\text { Ash } & 9.42 & 7.23 & 6.23 & 7.98 \\ \mathrm{~N} \times 6.25 & 16.52 & 14.77 & 10.95 & 19.82 \\ \text { Ether extract } & 3.29 & 2.84 & 3.18 & 2.48 \\ \text { Crude fibre } & 27.12 & 25.02 & 29.50 & 25.16 \\ \text { Lignin } & 3.81 & 3.51 & 4.80 & - \\ \text { Cellulose } & 32.76 & 29.91 & 33.92 & - \\ \text { Soluble carbohydrate } & - & 7.61 & 6.53 & -\end{array}$

Botanical composition ( $\%$ of dry matter)

$\begin{array}{lcccc}\text { Ryegrass } & \text { The sward } & 66 \cdot 4 & 69 \cdot 6 & 4 \cdot 0 \\ \text { Timothy } & \text { consisted } & - & - & 34 \cdot 8 \\ \text { Meadow fescue } & \text { of } \mathrm{S} 23 & - & - & 21 \cdot 7 \\ \text { Cocksfoot } & \text { ryegrass } & 17 \cdot 8 & 16 \cdot 6 & 2 \mathrm{I} \cdot 9 \\ \text { Other grasses } & \text { with less } & 10 \cdot 1 * & 11 \cdot 9 * & 17 \cdot 5+ \\ \text { Clovers } & \text { than } 10 \% & 0.0 & 0.0 & 0 \cdot 0 \\ \text { Weeds } & \text { of cocksfoot } & 5 \cdot 7 & 1 \cdot 9 & 0 \cdot 1\end{array}$

* Mostly Poa pratensis L.

$\dagger$ Mostly Agropyron repens (L.) Beauv.

Table 2. Summary of results of metabolic trials with sheep given the same grass fresh or artificially dried. (Each entry is the mean value obtained with two sheep)

Energy (kcal/day)

\begin{tabular}{|c|c|c|c|c|c|c|c|c|c|c|c|}
\hline \multirow{2}{*}{$\begin{array}{l}\text { Expt } \\
\text { no.* }\end{array}$} & \multirow[b]{2}{*}{ Grass } & \multirow[b]{2}{*}{ Intake } & \multirow[b]{2}{*}{ Faecal } & \multirow[b]{2}{*}{ Urinary } & \multirow[b]{2}{*}{$\mathrm{CH}_{4}$} & \multirow[b]{2}{*}{ Heat } & \multirow{2}{*}{$\begin{array}{c}\text { Mean } \\
\text { reten- } \\
\text { tiont }\end{array}$} & \multicolumn{4}{|c|}{$\mathbf{N}$ (g/day) } \\
\hline & & & & & & & & Intake & Faecal & Urinary & Retained \\
\hline I $a$ & $\begin{array}{l}\text { Fresh } \\
\text { Dried }\end{array}$ & $\begin{array}{l}5000 \\
5037\end{array}$ & $\begin{array}{l}\text { r } 488 \\
\text { r } 537\end{array}$ & $\begin{array}{l}233 \\
274\end{array}$ & $\begin{array}{l}378 \\
359\end{array}$ & $\begin{array}{l}2564 \\
2297\end{array}$ & $\begin{array}{l}33^{8} \\
57^{\circ}\end{array}$ & $\begin{array}{l}30 \cdot 48 \\
30.70\end{array}$ & $\begin{array}{l}8 \cdot 15 \\
8 \cdot 50\end{array}$ & $\begin{array}{l}21 \cdot \circ 3 \\
19 \cdot 8 I\end{array}$ & $\begin{array}{l}1 \cdot 30 \\
2 \cdot 39\end{array}$ \\
\hline $\mathbf{I} b$ & $\begin{array}{l}\text { Fresh } \\
\text { Dried }\end{array}$ & $\begin{array}{l}5137 \\
5228\end{array}$ & $\begin{array}{l}1514 \\
1675\end{array}$ & $\begin{array}{l}230 \\
278\end{array}$ & $\begin{array}{l}380 \\
367\end{array}$ & $\begin{array}{l}2677 \\
2343\end{array}$ & $\begin{array}{l}337 \\
565\end{array}$ & $\begin{array}{l}30 \cdot 6 I \\
3 I \cdot I 2\end{array}$ & $\begin{array}{l}8 \cdot 40 \\
8 \cdot 59\end{array}$ & $\begin{array}{l}20 \cdot 39 \\
19.86\end{array}$ & $\begin{array}{l}I \cdot 82 \\
2 \cdot 67\end{array}$ \\
\hline $2 a$ & $\begin{array}{l}\text { Fresh } \\
\text { Dried }\end{array}$ & $\begin{array}{l}5334 \\
5334\end{array}$ & $\begin{array}{l}1197 \\
1283\end{array}$ & $\begin{array}{l}245 \\
239\end{array}$ & $\begin{array}{l}414 \\
4 I I\end{array}$ & $\begin{array}{l}2728 \\
2529\end{array}$ & $\begin{array}{l}720 \\
872\end{array}$ & $\begin{array}{l}28.08 \\
28.08\end{array}$ & $\begin{array}{l}7 \cdot 3^{8} \\
8 \cdot 63\end{array}$ & $\begin{array}{l}19 \cdot 44 \\
16 \cdot 17\end{array}$ & $\begin{array}{l}I \cdot 26 \\
3 \cdot 28\end{array}$ \\
\hline $2 b$ & $\begin{array}{l}\text { Fresh } \\
\text { Dried }\end{array}$ & $\begin{array}{l}533^{6} \\
533^{6}\end{array}$ & $\begin{array}{l}1573 \\
1637\end{array}$ & $\begin{array}{l}198 \\
242\end{array}$ & $\begin{array}{l}407 \\
418\end{array}$ & $\begin{array}{l}2642 \\
2505\end{array}$ & $\begin{array}{l}610 \\
617\end{array}$ & $\begin{array}{l}20.95 \\
20.95\end{array}$ & $\begin{array}{l}7 \cdot 21 \\
8 \cdot 05\end{array}$ & $\begin{array}{l}\text { I } 2 \cdot 18 \\
\text { I I } 39\end{array}$ & $\begin{array}{l}I \cdot 56 \\
I \cdot 5 I\end{array}$ \\
\hline $3 a$ & $\begin{array}{l}\text { Fresh } \\
\text { Dried }\end{array}$ & $\begin{array}{l}6274 \\
6295\end{array}$ & $\begin{array}{l}1712 \\
1888\end{array}$ & $\begin{array}{l}258 \\
290\end{array}$ & $\begin{array}{l}455 \\
419\end{array}$ & $\begin{array}{l}2804 \\
2654\end{array}$ & $\begin{array}{l}1093 \\
\text { I I } 88\end{array}$ & $\begin{array}{l}43 \cdot 69 \\
43 \cdot 83\end{array}$ & $\begin{array}{r}9 \cdot 62 \\
11.93\end{array}$ & $\begin{array}{l}28 \cdot 63 \\
26 \cdot 16\end{array}$ & $\begin{array}{l}5 \cdot 44 \\
5 \cdot 74\end{array}$ \\
\hline $3^{b}$ & $\begin{array}{l}\text { Fresh } \\
\text { Dried }\end{array}$ & $\begin{array}{l}6246 \\
6356\end{array}$ & $\begin{array}{l}x 695 \\
2040\end{array}$ & $\begin{array}{l}314 \\
340\end{array}$ & $\begin{array}{l}43 I \\
422\end{array}$ & $\begin{array}{l}2864 \\
2695\end{array}$ & $\begin{array}{l}1051 \\
1007\end{array}$ & $\begin{array}{l}44 \cdot 49 \\
45 \cdot 27\end{array}$ & $\begin{array}{r}9.64 \\
12.61\end{array}$ & $\begin{array}{l}28 \cdot 28 \\
25 \cdot 66\end{array}$ & $\begin{array}{l}5.97 \\
7.00\end{array}$ \\
\hline $3 c$ & $\begin{array}{l}\text { Fresh } \\
\text { Dried }\end{array}$ & $\begin{array}{l}3148 \\
3148\end{array}$ & $\begin{array}{l}782 \\
895\end{array}$ & $\begin{array}{l}163 \\
172\end{array}$ & $\begin{array}{l}240 \\
230\end{array}$ & $\begin{array}{l}1876 \\
1745\end{array}$ & $\begin{array}{l}126 \\
180\end{array}$ & $\begin{array}{l}21 \cdot 92 \\
21 \cdot 92\end{array}$ & $\begin{array}{l}4.44 \\
5.97\end{array}$ & $\begin{array}{l}\text { I6.67 } \\
\text { I } 3.94\end{array}$ & $\begin{array}{l}0.81 \\
2.01\end{array}$ \\
\hline $3^{d}$ & $\begin{array}{l}\text { Fresh } \\
\text { Dried }\end{array}$ & $\begin{array}{l}3178 \\
3178\end{array}$ & $\begin{array}{l}791 \\
846\end{array}$ & $\begin{array}{l}191 \\
216\end{array}$ & $\begin{array}{l}239 \\
238\end{array}$ & $\begin{array}{l}1804 \\
1802\end{array}$ & $\begin{array}{l}211 \\
162\end{array}$ & $\begin{array}{l}22 \cdot 64 \\
22 \cdot 64\end{array}$ & $\begin{array}{l}4.53 \\
5 \cdot 40\end{array}$ & $\begin{array}{l}17 \cdot 15 \\
15 \cdot 64\end{array}$ & $\begin{array}{l}0.96 \\
1.60\end{array}$ \\
\hline
\end{tabular}

* I $a$ Sheep 106 and 107, rst 10 days of Expt I. $3 a$ Sheep 106 and 107, high I $b$ Sheep 106 and 107, and 10 days of Expt $1 . \quad 3^{b}$ Sheep 104 and 105, high $2 a$ Sheep 106 and 107, Expt 2. $2 b$ Sheep 104 and 105, Expt 2. $3 c$ Sheep ro6 and 107, low $\}$ level of grass intake, Expt 3 . $3 d$ Sheep 104 and 105 , low

+ Mean of retention estimated from heat measurements and that calculated from $\mathrm{C}$ and $\mathrm{N}$ retentions. 
of the sheep when given dried grass was $I \cdot I \%$ higher than when fresh grass was given. It will be noted that the heat production and, to a lesser extent, the methane production of the sheep, whether they received fresh or dried grass, reflected this day-to-day variation in dry-matter intake.
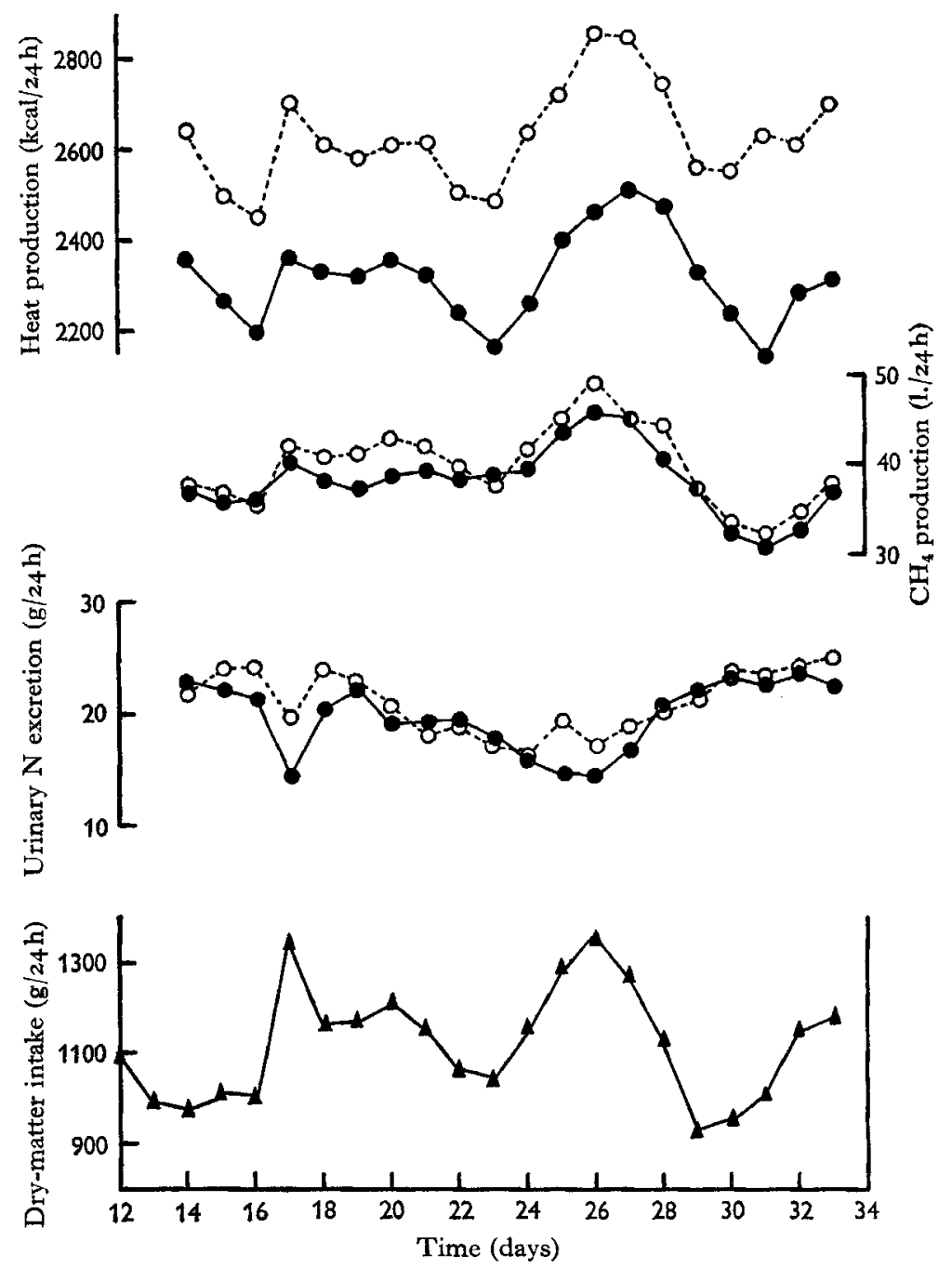

Fig. I. Dry-matter intake, urinary nitrogen excretion, $\mathrm{CH}_{4}$ production and heat production of sheep 106 and 107 in Expt I. A__- dry-matter intake; $0 .--0$, losses on fresh grass; - , losses on dried grass.

The urinary excretion of $\mathrm{N}$ and the methane production were slightly higher with. the fresh grass than with the dried. The heat production noted with fresh grass was very considerably greater than when the same grass was given dried despite the fact that the sheep given dried grass consumed slightly more. There was no indication of convergence of the two graphs of heat production with time. This finding shows that the sheep were completely at ease and trained at the beginning of the experiment, and 
that the difference in heat production noted was due to the nature of the food and not to a diminution of metabolism of the sheep given dried grass resulting from their continued sojourn and acclimatization to the conditions in the respiration chambers.

Fig. 2 shows the mean results obtained in Expt 2 with the two sheep used in Expt I. In this experiment dry-matter intake was controlled more accurately than in Expt I,
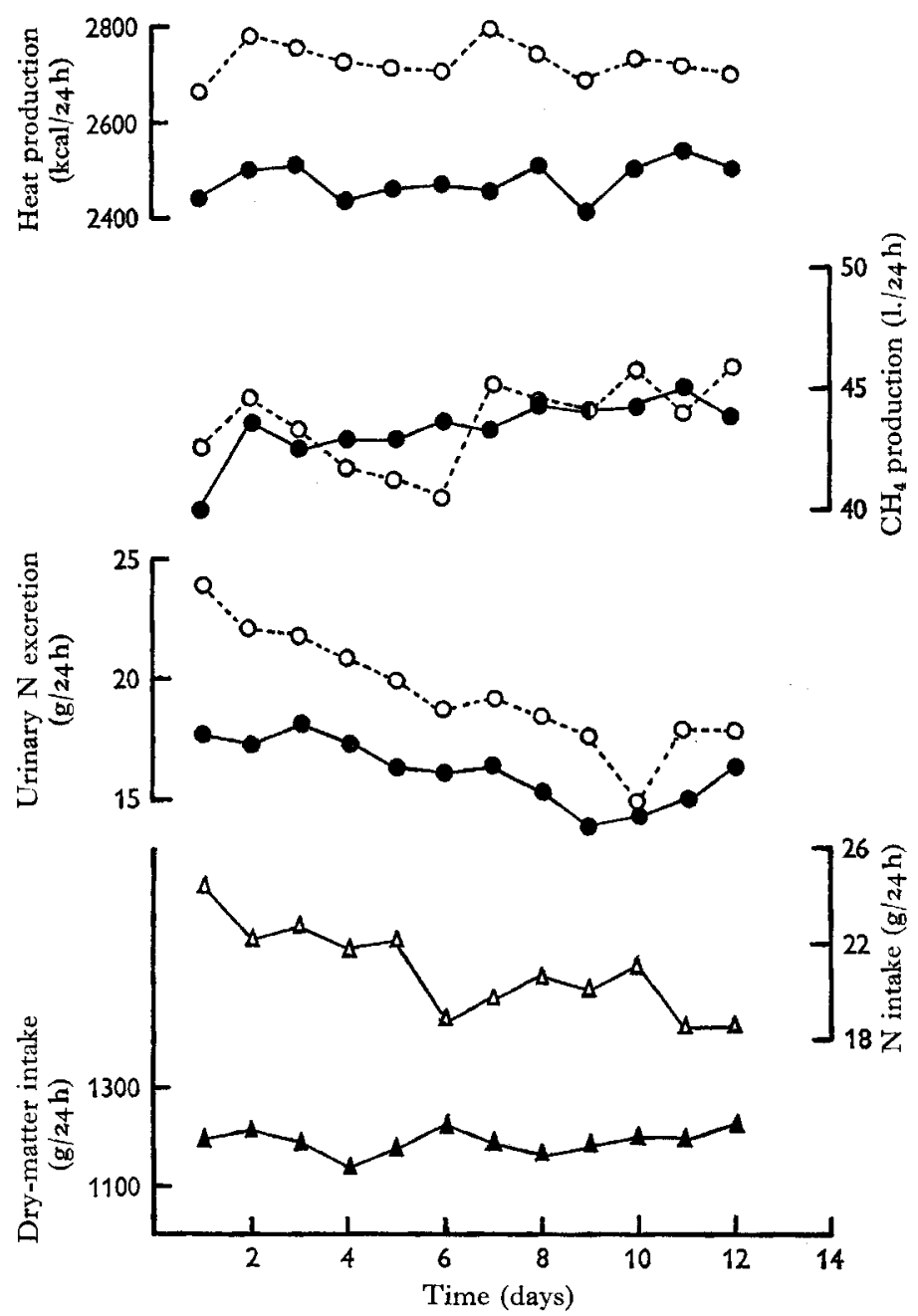

Fig. 2. Dry-matter and nitrogen intake, urinary $\mathrm{N}$ excretion, $\mathrm{CH}_{4}$ and heat production of sheep 106 and 107 in Expt 2. $-\Delta$, dry-matter intake; $\triangle \longrightarrow \Delta, \mathrm{N}$ intake; $0 \ldots \ldots$, losses on fresh grass; -__ losses on dried grass.

and the potential systematic error due to continued respiration of the fresh grass stored in the chambers before feeding was obviated by opening the chamber at $10.00 \mathrm{pm}$. It will be noted that there was a correlation between the daily dry-matter intake and heat production and a slight delay in maxima and minima of heat production with the sheep given dried grass compared with those given fresh grass. This was observed in 
Expt I also (Fig. I). In this experiment the sheep given fresh grass excreted more $\mathrm{N}$ in the urine than those given dried, the difference being greater early in the experiment when the $\mathrm{N}$ intake was high. Methane production was virtually the same with both fresh and dried grass, but heat production was again considerably greater when fresh rather than dried grass was given. This experiment in which the sheep were con-
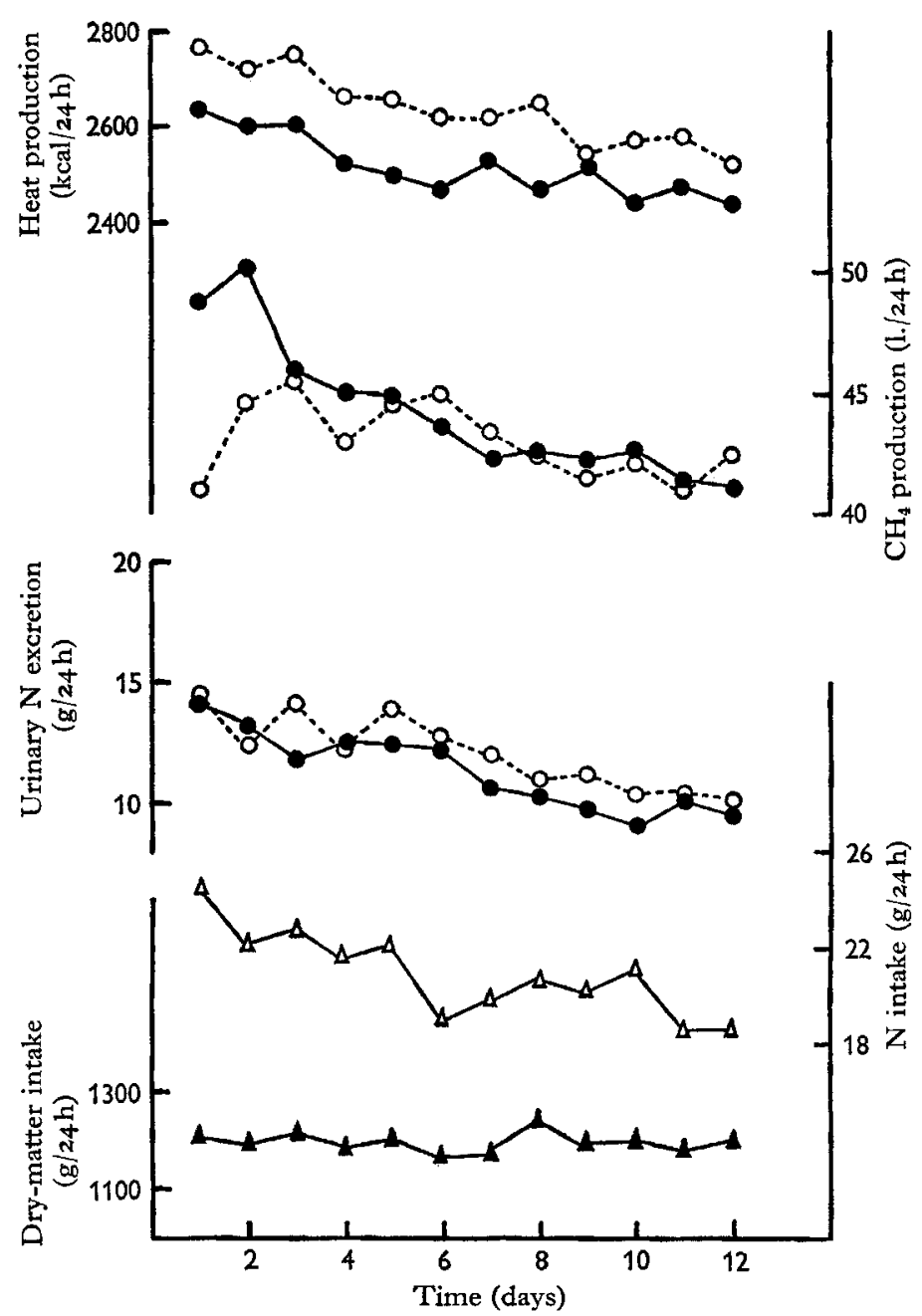

Fig. 3. Dry-matter and nitrogen intake, urinary $\mathrm{N}$ excretion, $\mathrm{CH}_{4}$ production and heat production of sheep 104 and 105 in Expt 2 . $\triangle \longrightarrow-\Delta$, dry-matter intake; $\triangle-\triangle \longrightarrow$, $\mathrm{N}$ intake; $0_{--.-0}$, losses on fresh grass; - $-\bullet$, losses on dried grass.

tinuously in respiration chambers for virtually 9 months certainly showed that the higher heat production with fresh grass could not be due to training of the sheep. It also shows, as was found by direct experiment (see p. 419), that continued respiration of the fresh grass in the respiration chamber was not responsible for the difference in heat production. 
Fig. 3 shows the mean results obtained with sheep I04 and 105 in Expt 2. In this experiment the grass given was beginning to flower and a downward trend in heat production and methane production with advancing maturity of the grass is evident. The results otherwise are very similar to those noted in Figs. I and 2 with sheep 106 and 107 . The high metabolism of sheep 106 and 107 when given fresh grass was thus not due to an individual idiosyncrasy.

From Table 2 it is evident that in Expt 3, in which the chambers were opened at I $0.00 \mathrm{pm}$ to give the sheep their meals of both fresh and dried grass, heat production when $\mathrm{I}_{4} 4 \mathrm{~kg}$ dry matter as fresh grass were given averaged $2834 \mathrm{kcal} / 24 \mathrm{~h}$, and when the same amount of dried grass was given it averaged $2675 \mathrm{kcal} / 24 \mathrm{~h}$. The difference is of the same order as that noted in Expt 2 and shows that the high heat production was not the result of a disturbance and consequent elevation of the metabolism of the sheep when they were given their evening meal of fresh grass.

Table 3. Mean losses of energy in faeces, as methane, and in urine, and the metabolizable energy of fresh grass and the same grass artificially dried when given to sheep

(Mean of sixteen values from all three experiments)

\begin{tabular}{|c|c|c|c|c|}
\hline & $\begin{array}{l}\text { Fresh } \\
\text { grass }\end{array}$ & $\begin{array}{l}\text { Artificially } \\
\text { dried } \\
\text { grass }\end{array}$ & $\begin{array}{l}\text { Standard } \\
\text { error of } \\
\text { mean }\end{array}$ & $\begin{array}{c}\text { Difference } \\
\text { between means } \\
\text { (fresh-dried) }\end{array}$ \\
\hline & \multicolumn{4}{|c|}{ kcal/roo kcal ingested } \\
\hline $\begin{array}{l}\text { Loss of energy in faeces } \\
\text { Loss of energy as methane } \\
\text { Loss of energy in urine } \\
\text { Metabolizable energy of grass }\end{array}$ & $\begin{array}{r}26 \cdot 93 \\
7 \cdot 46 \\
4 \cdot 70 \\
60 \cdot 92\end{array}$ & $\begin{array}{r}29 \cdot 31 \\
7 \cdot 22 \\
5 \cdot 25 \\
58 \cdot 22\end{array}$ & $\begin{array}{l} \pm 0.35 \\
\pm 0.06 \\
\pm 0.13 \\
\pm 0.38\end{array}$ & $\begin{array}{l}-2 \cdot 38 * * * \\
+0 \cdot 24 * \\
-0.55^{* *} \\
+2 \cdot 70^{* * *}\end{array}$ \\
\hline
\end{tabular}

The results of the three experiments taken together show that any differences in heat production between fresh and dried grass cannot be ascribed to systematic errors arising from acclimatization of the sheep to the conditions of the experiment, or to the conditions of the experiment, or to the continued respiration of fresh herbage within the respiration apparatus or to disturbance of the sheep during feeding. This means that the results of all the comparisons between fresh and dried grass can be pooled for analysis provided that the heat productions obtained when fresh grass was given in Expt $\mathrm{I}$ and recorded in Table 2 are reduced by $10 \mathrm{kcal} / \mathrm{day}$, the heat equivalent of the $4 \mathrm{~g} \mathrm{CO}_{2}$ produced from one meal of grass stored in the chamber for $\mathbf{I 2} \mathrm{h}$.

Losses of energy in faeces, urine and methane and the metabolizable energy of fresh and dried grass. Table 3 summarizes the mean results of the three experiments, comprising the sixteen comparisons that were made. The table shows that sheep when given the grass fresh excreted less of its energy in faeces and in urine and more of its energy as methane, and that these effects were statistically significant. Clearly the major difference between the fresh and dried grass was in the faecal loss of energy which increased on drying by $2.4 \mathrm{kcal} / \mathrm{I} 00 \mathrm{kcal}$ ingested. In Fig. 4, individual values obtained 
with dried grass have been plotted against those obtained with fresh grass and they show no systematic differences that might be ascribed to the differences in the amounts of energy lost in faeces, urine or methane when fresh grasses of different feeding values were given.

Table 3 shows that the metabolizable energy of the herbage was greater by $2 \cdot 7 \mathrm{kcal} /$ roo kcal food when it was given fresh than when it was given dried. This represents a decline of $4.4 \%$ in the metabolizable energy of unit weight of grass when it was artificially dried.

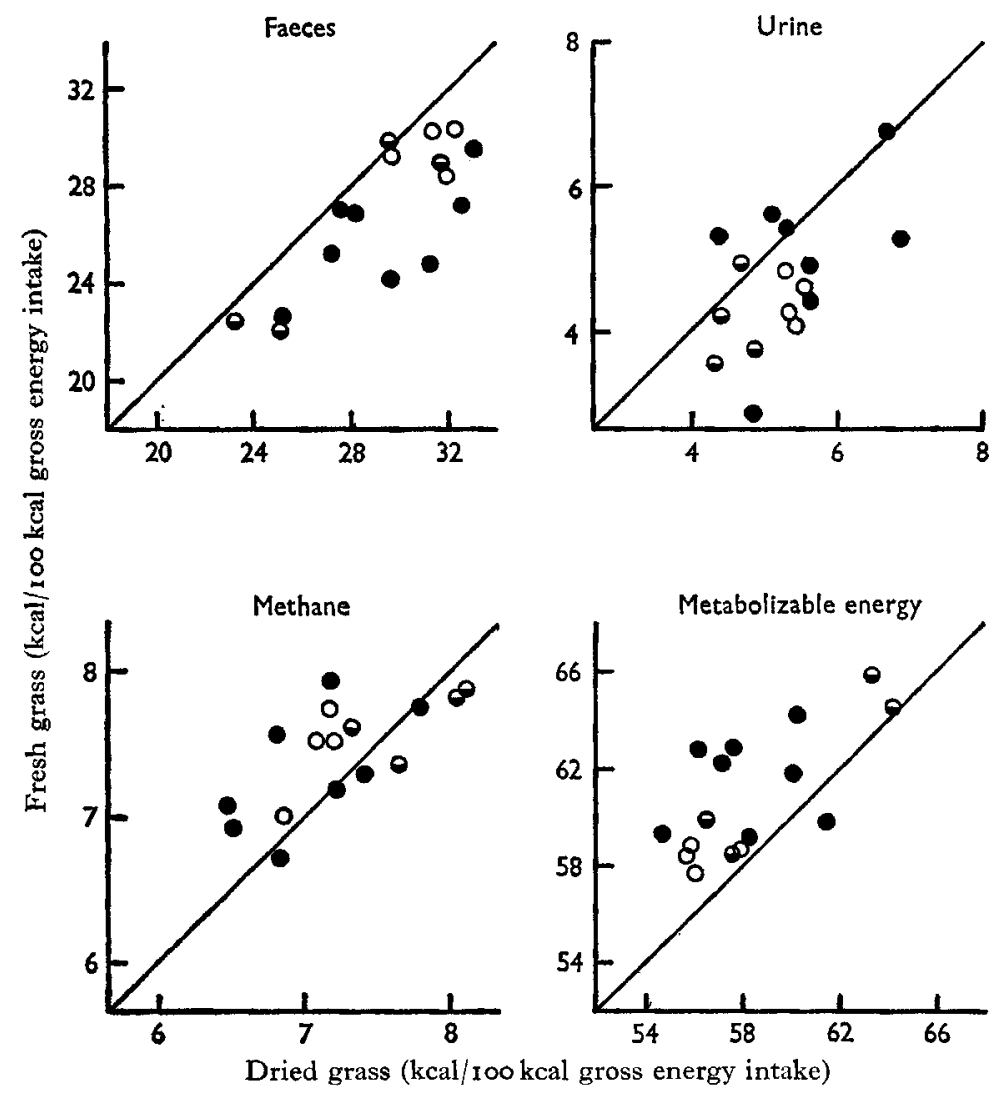

Fig. 4. Losses of energy in faeces, urine, and as $\mathrm{CH}_{4}$, and the amount of metabolizable energy, per roo kcal gross energy intake of individual sheep given fresh or dried grass. 0 , Expt I; $\odot$, Expt 2; •, Expt 3 .

Metabolism of $N$. Table 4 summarizes the faecal and urinary loss of $\mathrm{N}$ and the $\mathrm{N}$ retained by the sheep when given fresh or dried herbage. When given the grass fresh, the sheep excreted $\mathrm{r} \cdot 3 \mathrm{~g}$ less $\mathrm{N}$ in faeces and $2.0 \mathrm{~g}$ more $\mathrm{N}$ in urine. These effects were highly significant statistically. When given fresh grass, particularly autumn grass in Expt I, the sheep rejected very small amounts. They did not do so when given dried grass. When dried grass was given the mean intake of $\mathrm{N}$ was therefore $0.2 \mathrm{~g} /$ day higher than when the mean of $30.36 \mathrm{~g} \mathrm{~N}$ as fresh grass was given. This accounts for the apparent discrepancy in Table 4 when its rows and columns are summed. The 
apparent superiority of dried grass compared with fresh grass in terms of $\mathrm{N}$ retention is thus a slight overestimate but, in any event, the differences in $\mathrm{N}$ retention were not statistically significant. Artificial drying thus increased the faecal loss and diminished the urinary loss of $\mathrm{N}$ without affecting $\mathrm{N}$ retention.

Artificial drying of the grass increased the loss of energy in urine (Table 3 ) but diminished the loss of $\mathrm{N}$ in urine (Table 4 ). The ratio of energy to $\mathrm{N}$ in urine thus increased considerably as shown in Table 4 . The increase was $25 \%$, and since the ratio of energy to carbon in urine is very constant this finding suggests that artificial drying results in the formation of compounds which lead to increases in the loss of carbon-containing compounds in urine. Their nature has not been examined.

\section{Table 4. Mean $N$ metabolism of sheep given fresh grass or the same grass artificially dried}

(Mean of sixteen values from all three experiments)

\begin{tabular}{|c|c|c|c|c|}
\hline & $\begin{array}{l}\text { Fresh } \\
\text { grass }\end{array}$ & $\begin{array}{l}\text { Artificially } \\
\text { dried } \\
\text { grass }\end{array}$ & $\begin{array}{l}\text { Standard } \\
\text { error of } \\
\text { mean }\end{array}$ & $\begin{array}{c}\text { Difference } \\
\text { between means } \\
\text { (fresh }- \text { dried) }\end{array}$ \\
\hline Loss of $N$ in faeces ( $g /$ day) & $7 \cdot 43$ & 8.71 & \pm 0.15 & $-1 \cdot 28 * * *$ \\
\hline Loss of $\mathrm{N}$ in urine ( $\mathrm{g} /$ day) & 20.54 & $18 \cdot 58$ & \pm 0.27 & $+I \cdot 96 * * *$ \\
\hline $\mathrm{N}$ retained (g/day) & $+2 \cdot 39$ & +3.27 & \pm 0.30 & $-0.88 \mathrm{NS}$ \\
\hline Ratio, energy: $\mathrm{N}$ in urine & II.43 & $143^{6}$ & \pm 0.30 & $-2 \cdot 93^{* * *}$ \\
\hline
\end{tabular}

NS, not statistically significant.

*** Statistically significant, $P<0.001$.

Table 5. Mean heat production and mean energy retention by sheep given fresh and dried grass, and mean increases in heat production above the fasting level as percentages of the metabolizable energy

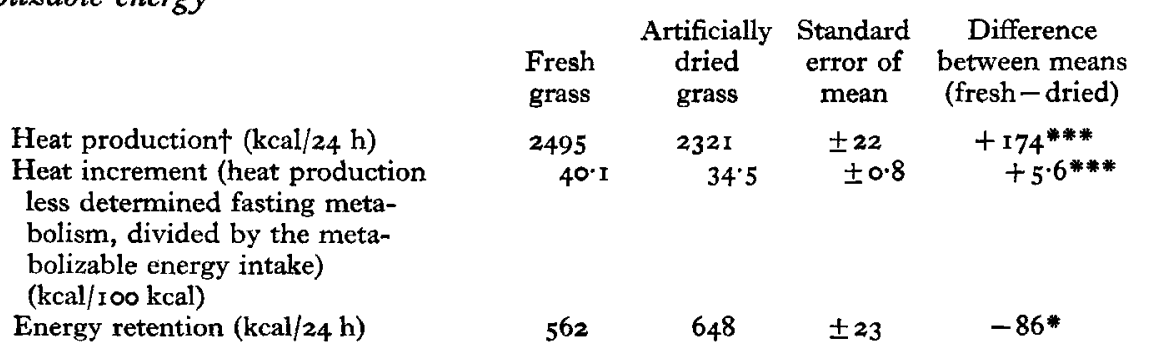

* Statistically significant, $P<0.05$.

*** Statistically significant, $P<0.001$.

$\dagger$ In arriving at the mean values for heat production, the heat production determinations when fresh grass was given in Expt I have been reduced by $10 \mathrm{kcal} /$ day for reasons given on $\mathrm{p} .425$.

Heat production and energy retention. In Table 5 the observed mean values for the heat production and energy retention by the sheep are given, and individual comparisons for heat production are plotted in Fig. 5. The energy retention values are the means of those determined from the $\mathrm{C}$ and $\mathrm{N}$ retentions and the heat measurements. In Expt I, however, the balances are those determined from heat measurements alone. Heat production was $7 \%$ higher and energy retention was $13 \%$ lower 
when fresh grass was given than when dried grass was given, and the differences were statistically significant. The lower energy retention from fresh grass is particularly noteworthy since the sheep received more metabolizable energy from fresh grass.

These values in Table 5, though they show that heat production is higher when fresh grass rather than dried grass is given, do not reflect the true effect of the herbage because, first, the metabolizable energy intakes were not the same and, secondly, a proportion of the heat production represents the inevitable expenditure of energy in
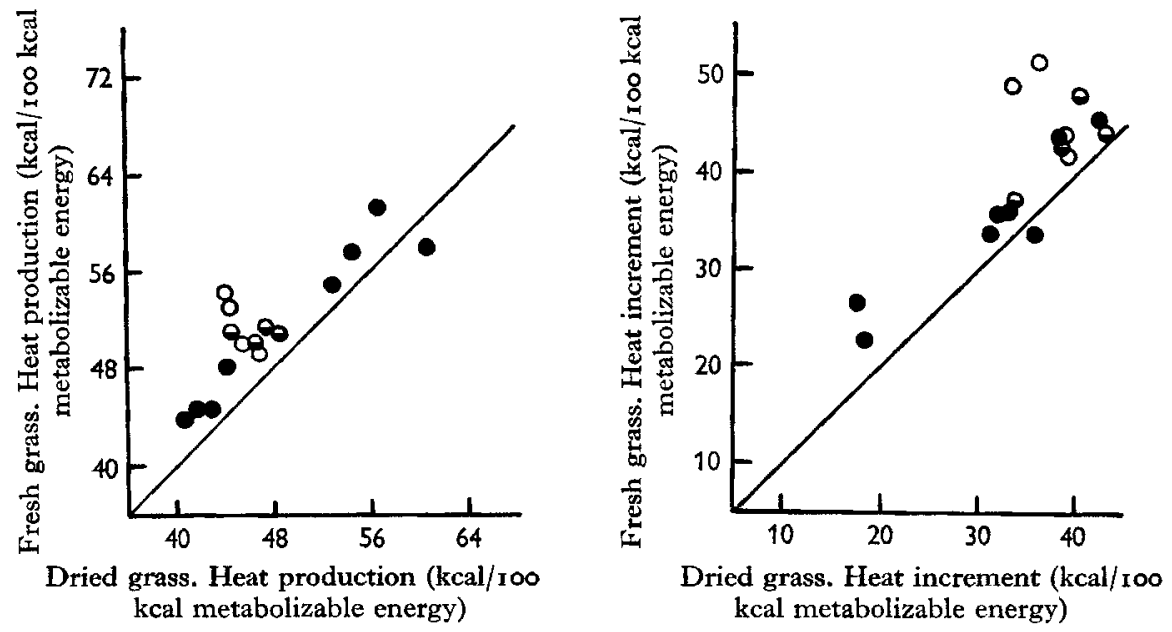

Fig. 5. Heat production and heat increment in individual sheep when given fresh or dried grass. 0, Expt $\mathrm{r} ; \ominus$, Expt $2 ; \bullet$, Expt 3.

maintenance. The total heat increments were therefore computed as the observed heat production less the fasting heat production $(F)$, calculated according to the formula:

$$
F=F^{1} W^{0.73},
$$

where $F^{\mathbf{1}}$ is the fasting metabolism/kg $W^{\mathbf{0} \cdot 73}$ directly determined and $W$ the weight of the sheep in a particular trial. The value obtained by dividing the heat increments by the metabolizable energy intake represents the increase in heat production which occurs when a food is given. The results of this calculation are given in Table 5 and Fig. 5. They show that the increment of heat/100 kcal metabolizable energy was greater by $16 \%$ for fresh grass than for dried, and that this difference was statistically significant. Conversely, net energy/100 kcal metabolizable energy from fresh grass was lower than from dried grass. Net energy in this context is the sum of the fasting heat production and energy retention.

The design of Expt 3 in which two different amounts of grass were given permits direct estimation of the efficiency of utilization of the net energy of fresh and dried herbage for fattening of the sheep (see Armstrong, 1964). From the results in Table 2 and the body-weights of the sheep, the efficiency of utilization for fattening was calculated. It was found that the efficiency of utilization of the metabolizable energy of fresh grass for fattening was $50.4 \%$ and of the dried grass $55 \cdot x \%$. The mean maintenance requirement as metabolizable energy of the sheep given fresh grass was 
$1690 \mathrm{kcal} / 24 \mathrm{~h}$ and of those given dried grass $1564 \mathrm{kcal} / 24 \mathrm{~h}$. Maintenance requirements of metabolizable energy with fresh grass were thus $8 \%$ higher and the efficiency of utilization of metabolizable energy for fattening was $9 \%$ lower than when dried grass was given. In this third experiment the increase in nutritive value on drying was less than the average for all the experiments. It is not known whether this was due to the type of herbage given but, in any event, the results of this experiment with a timothy-fescue pasture show that, as with predominantly ryegrass pasture, the nutritive value of the dried herbage was greater than that of the fresh.

Body-weight gains. In Expt 2 gains in body-weight were recorded and the gains in this experiment were not complicated by the changes in fill of the gut which were clearly present in Expt $\mathrm{I}$. The mean gain/day of sheep given fresh grass was $23^{8} \mathrm{~g}$ and that of sheep given dried grass was $53^{8} \mathrm{~g}$. The difference, suggesting a considerable superiority of dried over fresh grass, was statistically significant $(P<0.05)$.

Course of $\mathrm{O}_{2}$ consumption after a meal. In Expts I and 2 the sheep appeared to be more avid for their meal of fresh grass than for their meal of dried grass. This behaviour suggested that part of the reason for the higher heat production might be psychological, similar to that observed by Blaxter \& Joyce (1963) to occur when food was offered to a hungry sheep or when sheep were sham-fed. To examine this possibility in each of the calorimetric periods of Expt $3, \mathrm{O}_{2}$ consumption was determined at intervals after the consumption of a meal, and the results are shown in Fig. 6. The results do not show any systematic trends in $\mathrm{O}_{2}$ consumption. This would not suggest a psychological cause of the high heat production noted when fresh grass was given.

Time taken to consume fresh and dried herbage. The time taken to consume single meals of fresh and dried herbage was determined on sixteen occasions with each of the four sheep in Expt 3. When 350 g of grass dry matter were given in a meal, the sheep consumed the fresh herbage in $24 \mathrm{~min}$ and the dried herbage in $16 \mathrm{~min}$. When $700 \mathrm{~g}$ of grass dry matter were given in a meal the sheep consumed the fresh herbage in $63 \mathrm{~min}$ and the dried herbage in $44 \mathrm{~min}$. The sheep thus took about $50 \%$ longer to consume fresh grass than dried grass. The absence (Fig. 6) of a markedly greater $\mathrm{O}_{2}$ consumption of sheep eating fresh grass during the ist $h$ after feeding, when compared to that of the sheep eating dried grass, suggests that the increased time taken to eat fresh grass had little effect on the heat production of the sheep.

Water consumption and heat production. Because of continuous rain the fresh grass given in Expt I contained much adventitious water and the total water intake was $7 \cdot 11$ /day. The sheep consumed no additional water though this was available. When dried grass was given the total intake of water was $2 \cdot 91$./day. The difference of 4.21 . water/day must have been warmed to body temperature and much of the heat required to warm it would be needed rapidly since a single meal of fresh grass was consumed in about $\mathrm{I} h$. It was conceivable that this demand for heat might accelerate metabolism even in a well-fleeced sheep. That it did not do so is already evident in Fig. 6, which does not show any greater immediate rise in $\mathrm{O}_{2}$ consumption after the 
meal of fresh than of dried grass. The subsidiary experiment, the results of which are summarized in Table 6 , show that when $I^{\cdot} 5$ l. water were introduced into the rumen per meal no increase in heat production occurred. A slight increase was apparent

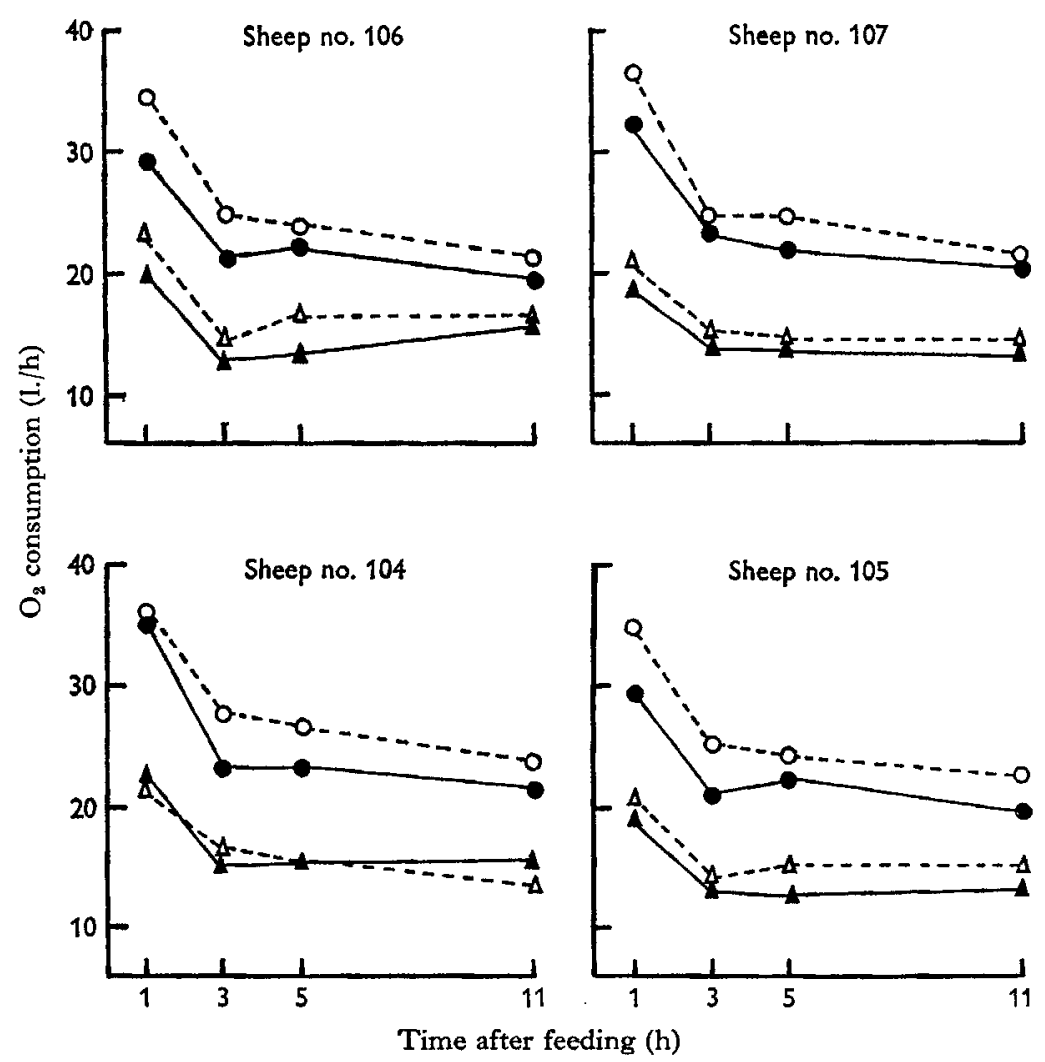

Fig. 6. Oxygen consumption of individual sheep in Expt 3. $\circ \ldots-$. , fresh grass, high feeding level; $\bullet \ldots \bullet$, dried grass, high feeding level; $\Delta \ldots \Delta$, fresh grass, low feeding level; $\mathbf{\Delta}$, dried grass, low feeding level.

Table 6. Effect on heat production of infusion of water at $5^{\circ}$ into the rumen of a sheep given dried grass and kept in an environment of 8-10

$\begin{array}{lccc}\text { Treatment given } & \begin{array}{c}\text { No. of } \\ \text { observations }\end{array} & \begin{array}{c}\text { Heat production } \\ \text { (kcal/24 h) }\end{array} & \begin{array}{c}\text { Increase due to } \\ \text { water (kcal/24 h) }\end{array} \\ \text { None } & 9 & 2137 \pm 9.9 & - \\ \text { I.5 1. water/meal } & 6 & 2160 \pm 8 \cdot 8 & \text { I2 } 13.3 \\ \text { 3.0 1. water/meal } & 4 & 2201 \pm 26.3 & 64 * 28.0\end{array}$

* Statistically significant, when $P=0.05$.

after the introduction of 31 . water at $5^{\circ}$ when the sheep were kept in the chambers at a temperature of 8-10 $0^{\circ}$. A total of $204 \mathrm{kcal}$ would be required to warm the 3.01 . water, given twice daily, from $5.0^{\circ}$ to $39^{\circ}$, the body temperature of the sheep. The experiments showed, however, that heat production rose by only $64 \mathrm{kcal}$, which is 
about a third of the total. The additional amount of water consumed by a sheep given fresh grass over that consumed by the same sheep given dried grass was never more than 4.51 . day; the experiments with fresh grass were all made at environmental temperatures of $18^{\circ}$ or above and, in any event, the temperature of the morning meal of grass was never as low as $5^{\circ}$, whereas the temperature of the evening meal was usually about $18-20^{\circ}$. It seems unlikely that the differences between the heat productions of sheep given dried and fresh grass were due to the heat required to warm the water in the fresh grass.

\section{DISCUSSION}

The results of the experiments show that the metabolizable energy of fresh grass is $4 \%$ greater than that of the same grass dried, but that the heat production from the metabolizable energy of fresh grass is on average $16 \%$ greater than that of the same grass when artificially dried. The result is that the energy retention observed when dried grass is given is greater than when the same amount of the same grass is given to the same sheep in the fresh state.

In reaching this conclusion care has been taken to rule out the effects of any possible systematic source of error. It has been shown that no mechanical losses occurred during the drying process and that though some small loss of volatile $\mathrm{N}$ occurred during drying there was no measurable loss of organic matter, as judged by comparison of the ash content of fresh and dried herbage. Continued respiration of the grass in the respiration chamber produced a small systematic error in the heat measurements in the first experiment. This has been allowed for in the final analysis. Opening of the respiration chamber to give the sheep their evening meal of fresh grass was discounted as the cause of the higher heat production from fresh than from dried grass. Training of the sheep to conditions in the chamber could hardly have been the cause of the difference in heat production; the sheep were very highly trained and had been under the same régime for nearly 3 years when the experiments terminated. A small systematic error is introduced by the method of calculating the heat increment as a percentage of the total metabolizable energy because, since these increments are total increments, they represent the sum of the increments for maintenance and for production. These separate increments of heat for food with a mean metabolizable energy of $60 \%$ are about 28 and $50 \%$, respectively. The higher the metabolizable energy intake, the greater is the total heat increment. The $4 \%$ higher intake of metabolizable energy by the sheep given fresh grass, however, would, at the levels of energy retention attained, result in but a minor increase in total heat increment. This systematic error does not account for the differences observed. In any event, despite the higher metabolizable energy intake of sheep given fresh grass, these sheep gained less body-weight than those given dried grass. As far as it has been possible to ascertain, therefore, the conclusions drawn above are not invalidated by any systematic errors. As far as heat losses are concerned, the findings are contrary to those of Heinzl (1944).

The biological reasons for the differences between the utilization of the energy of fresh and dried grass have been investigated and considered. First, the higher heat 
production and lower faecal loss of energy when fresh rather than dried grass was given was not due to the higher water intake from fresh herbage. Secondly, it was not due to a psychological disturbance associated with the sight or smell of fresh grass. These aspects have been dealt with experimentally. A third possibility is that drying might destroy a factor or factors in fresh grass which stimulate metabolism; oestrogens are an obvious example. Artificial drying partly inactivated oestrogens (Bickoff, Booth, Livingston, Hendrickson \& Lyman, 1959; Bickoff, Booth, Livingston \& Hendrickson, 1960; Bickoff, Livingston, Booth, Hendrickson \& Kohler, I960). Oestrogens, however, have no effect on heat production (Peters \& Van Slyke, I946), and if present in fresh but absent in dried herbage might be expected to lead to considerably greater $\mathrm{N}$ retentions by the sheep given the fresh herbage than by those given the dried herbage (Whitehair, Gallup \& Bell, 1953; Clegg \& Cole, r954; Preston, Rochanasaroj \& Gee, 1958). In fact, there was no difference in $\mathrm{N}$ retention and so oestrogens can probably be discounted. Whether other factors present in fresh herbage but destroyed on drying are responsible is not known.

The fourth, and to us the most likely, possible reason for the discrepancy stems from the evidence that others have obtained, as cited in the introduction to this paper, that the bacterial and digestive processes in ruminants given fresh grass and dried grass differ. Our experiments provide further indirect evidence that differences in the digestion of fresh and dried herbage might be considerable. The energy of fresh herbage was digested better than that of the dried, and more $\mathrm{N}$ was apparently absorbed from it, to be excreted in the urine. The low absorption of $\mathrm{N}$ from dried grass is probably related to denaturation of the grass protein by heat and to lowered absorption of $\mathrm{N}$ as ammonia. Furthermore, the indirect evidence from the correlation of heat production and food intake in Fig. I, and to a lesser extent in Figs. 2 and 3 , suggests a slower rate of metabolism of unit dried grass than of unit fresh grass. These observations all indicate a more active and rapid fermentation process in the sheep given fresh grass, as indeed does the observation that sheep given fresh grass produced more methane than those given dried grass. The sheep given fresh grass may well have produced more heat as a result of bacterial processes in the rumen. This heat is necessarily included in the heat increments as calculated, as is any heat liberated when energy is used to synthesize urea from ammonia absorbed from the gut.

\section{SUMMARY}

I. Sixteen comparisons were made between the energy metabolism of sheep given fresh-cut herbage and that of the same animals when given the same amount of herbage artificially dried. Four sheep were used in the experiments.

2. Care was taken to avoid systematic errors due to continued respiration of the herbage and to acclimatization of the sheep to the conditions of the experiment. Losses of organic matter on drying appeared to be negligible.

3. Sheep given fresh grass lost less energy in faeces and in urine and more energy as methane than did those given dried grass. The metabolizable energy of fresh grass was $4 \%$ higher than that of the same grass when dried. 
4. Sheep given fresh grass excreted $15 \%$ less nitrogen in the faeces and $11 \%$ more in the urine than those given dried grass. No differences occurred in $\mathrm{N}$ retention. The ratio of energy: $\mathrm{N}$ in urine was $26 \%$ greater with dried grass than with fresh grass.

5. Sheep given fresh grass produced more heat than those given dried grass. The increment of heat determined as the difference between the measured heat production and the fasting metabolism divided by the metabolizable energy was greater by $16 \%$ with the fresh than with the dried grass.

6. In one experiment in which different amounts of grass were given, the efficiency of utilization of metabolizable energy for fattening was $50.4 \%$ for fresh grass and $55.4 \%$ for dried grass. Body-weight gains were greater with fresh grass than with dried grass.

7. No differences between the two materials were found in the curves of $\mathrm{O}_{2}$ consumption after feeding, and separate experiments showed that the effect was not due to an increased water intake by sheep given fresh grass. The time taken to eat fresh grass was $50 \%$ greater than the time taken to eat the same amount of the same herbage when dried.

8. Alternative explanations of the effect of drying of grass on energy metabolism are discussed.

All the experiments with fresh grass involved continuous calorimetric work, and in addition, in Expts 2 and 3, the respiration chambers were opened at $10.00 \mathrm{pm}$ each night for periods of several months. Our colleagues shared with us the labour of much of this onerous routine and we are particularly grateful to $\mathrm{Mr} \mathrm{F}$. W. Wainman, Dr J. L. Clapperton and Mr J. P. Joyce for giving so freely of their evenings and Sundays in this work. Miss Breckenridge was responsible for the analytical work and Miss McKay for the calculations of respiratory metabolism.

\section{REFERENCES}

Armstrong, D. G. (I964). F. agric. Sci. 62, 399.

Armstrong, D. G., Blaxter, K. L. \& Waite, R. (1964). 7. agric. Sci. 62, 417.

Bickoff, E. M., Booth, A. N., Livingston, A. L. \& Hendrickson, A. P. (1960). F. Anim. Sci. 19, 745.

Bickoff, E. M., Booth, A. N., Livingston, A. L., Hendrickson, A. P. \& Lyman, R. L. (1959). F. Anim. Sci. 18, 1000.

Bickoff, E. M., Livingston, A. L., Booth, A. N., Hendrickson, A. P. \& Kohler, G. O. (r96o). F. Anim. Sci. 19, 189.

Blaxter, K. L. \& Joyce, J. P. (1963). Brit. F. Nutr. 17, 523.

Blaxter, K. L. \& Rook, J. A. F. (I953). Brit. F. Nutr. 7, 83 .

Christian, K. R. \& Williams, V. J. (1957). N.Z. F. Sci. Tech. 38A, 1003.

Clegg, M. T. \& Cole, H. H. (1954). Y. Anim. Sci. 13, 108.

Dijkstra, N. D. (1956). Landbouwvoorlichting, r3, 223.

El-Shazly, K. (1952). Biochem. Y. 5I, 640.

Heinzl, O. (1944). Der Einfluss der künstlichen Trocknung auf die energ etische Wirkung von Junggras, festgestellt durch Gesamtstoffwechselversuche am Schaf. Thesis, Eidgenössischen Technischen Hochschule, Zürich.

Johns, A. T. (1955). N.Z. Y. Sci. Tech. 37A, 323.

Peters, J. P. \& Van Slyke, D. D. (1946). Quantitative Clinical Chemistry, and ed. Vol. 1. London: Baillière, Tindall and Cox. 
Prabucki, A. L. (I963). Vergleichende Untersuchungen über den Einfluss von frischem und dehydratisiertem Gras auf die chemische Zusammensetzung des Panseninhaltes ausgewachsener Schafe. Thesis, Eidgenössischen Technischen Hochschule, Zürich.

Prabucki, A. L. \& Crasemann, E. (r96r). Proc. int. Congr. Anim. Prod. vilı. Hamburg, Vol. 3, p. 34.

Preston, T. R., Rochanasaroj, V. \& Gee, I. (1958). Proc. Brit. Soc. Anim. Prod. p. I3.

Wainman, F. W. \& Blaxter, K. L. (1958). EAAP Publ. no. 8, p. 85.

Whitehair, C. K., Gallup, W. D. \& Bell, M. C. (1953). F. Anim. Sci. 12, 33 I. 